\title{
ISLAM MENGHADAPI JUNTA MILITER DI MYANMAR
}

\author{
Mudji Hartono, Danar Widiyanta, dan Ririn Darini \\ Email: danar_widiyanta@uny.ac.id
}

\begin{abstract}
Abstrak
Islam mengalami pasang surut perkembangannya di Myanmar. Pada abad ke-1 Pedagang Arab sudah menempati wilayah sekitar Arakan. Pelaut Muslim telah datang ke Myanmar pada abad ke-9. Orang Arab muslim telah berperan dalam pemerintahan di Myanmar. Raja Sawlu (1077-1088), dididik oleh seorang guru muslim berkebangsaan Arab. Negara Islam didirikan di Arakan ketika Sultan Bengal yang beragama Islam Naseeuruddeen Mahmud Syah (1442-1459, membantu Raja Sulayman Naramitha membangun Negara Islam. Muslim di Myanmar juga melakukan perlawanan terhadap tindakan kesewenang-wenangan yang dilakukan oleh Junta Militer. Salah satu bentuk perlawanan mereka adalah membentuk organisasi, salah satunya adalah Oganisasi Nasional Arakan Rohingya (ARNO). Organisasi ini merupakan gabungan dari Front Islam Rohingya (ARIF) yang dipimpin oleh Nurul Islam, Organisasi Solidaritas untuk Rohingya (RSO) yang dipimpin oleh Dr. Yunus dan RSO pimpinan Prof. Muhamma Zakaria. Tahun 1996 terjadi intensitas yang tinggi perlakuan sewenang-wenang dari pemerintahan militer Myanmar. Puncaknya pasca peristiwa 11 September 2001 di Amerika Serikat mengakibatkan tekanan terhadap muslim Myanmar bertambah keras. Tercatat sekitar 1.500.000 muslim Myanmar harus mengungsi ke Malaysia, Bangladesh, Thailand dan lain-lain.
\end{abstract}

Kata Kunci : Islam, Junta Miiter, Myanmar

\begin{abstract}
Abstrac
Islam has been encountering the ups and downs during its existence in Myanmar. On the first century, Arabian trader occupied the Arakan area and its surrounding. Arabian Muslim sailors had come to Myanmar since the $9^{\text {th }}$ century had been playing a role in Myanmar government since then. The King Sawlu (1077-1088), had been educated by a Muslim with Arabian nationality. Islam Nation was established in Arakan when a Muslim Sultan Bengal, Naseerudden Mahmud Syah (1422-1459) helped The King Sulayman Naramitha to build Islam Nation. Muslim in Myanmar also battled the arbitrary done by Junta Military. One of the counterworks was by establishing organizations, one of them was Arakan Rohingya National Organization (ARNO). This organization was an alliance between Arakan Rohingya Islam Front (ARIF) led by Nurul Islam and Rohingya Solidarity Organization (RSO) led by Dr. Yunus and Prof. Muhamma Zakaria. During 1996, there occurred high intensity arbitrary by Myanmar Military Forces. The peak was the incident of 11 September 2001 on United States of America
\end{abstract}


which resulted higher pressure to Myanmar Muslim at the time. There recorded 1.500.000 Myanmar Muslims had the urgency to evacuate themselves to Malaysia, Bangladesh, Thailand, and other countries.

Key Words: Islam, Junta Military, Myanmar

\section{PENDAHULUAN}

Islam sampai ke Myanmar atau yang dulu sebelum 1972 disebut Burma, melalui beberapa jalan. Pedagang Arab sudah mulai datang dan menetap di sepanjang garis pantai Myanmar selama abad $1 \mathrm{H}$ (Abad VII M), atau sesudahnya. Awalnya para pedagang Arab ini menempati wilayah di kawasan sekitar pantai Arakan, baru kemudian ke arah Selatan. Para saudagar Arab yang beragama Islam ini mendarat di delta Sungai Ayeyarwady, Semenanjung Tanintharyi, dan Daerah Rakhin. Tahun-tahun berikutnya, para pedagang India dan Melayu telah efektif dalam menyebarkan Islam. Kedatangan umat Islam ini dicatat oleh orang-orang China, Eropa, dan Persia.

Para pelaut Muslim telah datang ke Myanmar pada abad ke 9 M. Para pengelana dari China pada tahun $860 \mathrm{M}$ menemukan daerah koloni Persia di perbatasan Yunnan. Seorang pelancong Persia, Ibnu Khordabheh, pelancong Arab abad IX, Sulaiman, dan pelancong Persia abad X, Ibnu Al-Faqih, dalam tulisantulisan mereka telah menyebut tentang daerah Burma Selatan ${ }^{1}$.

Al-Maqdisi, seorang sejarawan Arab yang hidup di abad X, membicarakan hubungan yang telah berkembang antara Burma dan India, Kepulauan Melayu dan Srilangka. Sejarah Burma mencatat posisi orang-orang Arab di masa pemerintahan Raja Anawartha (1044-1077) yang bekerja sebagai penunggang kuda baginda ${ }^{2}$. Penganti dari Raja Anawartha yaitu Raja Sawlu (1077-1088), dididik oleh seorang guru muslim berkebangsaan Arab. Raja mengangkat anak sang guru, Yaman Khan, sebagai Gubernur kota Ussa atau Pegu sekarang. Akibat konspirasi di kalangan istana, Yaman Khan melakukan pemberontakan. Usaha

${ }^{1}$ Omar Farauk, "Muslim Asia Tenggara dari Sejarah Menuju Kebangkitan Islam", dalam saiful Muzani (ed), Pembangunan dan Kebangkitan Islam di Asia Tenggara, LP3ES, Jakarta, 1973, hlm. 28.

${ }^{2}$ Ibid. 
untuk menguasai Pagan digagalkan oleh Kyanzittha saudara dari Sawlu. Sawlu tetap membolehkan adanya perkampungan muslim di pedalaman Burma. Di abad XIII, pada masa Raja Pagan Narathihpate (1255-1286) pasukan Kubilai Khan menyerang dan menguasai Nga Saung Chan. Pasukan Kubilai Khan di bawah pimpinan Nasrudin, anak gubernur Yunnan mampu menguasai wilayah Burma. Dengan demikian keberadaan muslim di Burma kembali terasa ${ }^{3}$.

Sebagian besar Muslim di Myanmar bekerja sebagai penjelajah, pelaut, saudagar dan tentara. Beberapa di antaranya bekerja sebagai penasihat politik Kerajaan Burma. Muslim Persia menemukan Myanmar setelah menjelajahi daerah selatan China. Koloni muslim persia di Myanmar ini tercatat di buku Chronicles of China di 860. Umat muslim asli Myanmar disebut Pathi dan muslim China disebut Panthay. Konon, nama Panthay berasal dari kata Parsi. Kemudian, komunitas muslim bertambah di daerah Pegu, Tenasserim, dan Pathein. Negara Islam didirikan di Arakan ketika Sultan Bengal yang beragama Islam Naseeuruddeen Mahmud Syah (1442-1459, membantu Raja Sulayman Naramitha membangun Negara Islam ${ }^{4}$.

Berdasar latar belakang masuknya Islam di Myanmar, berikutnya akan dibahas berbagai masalah sebagai berikut : bagaimana perkembangan Islam di Myanmar zaman kasultanan Islam, bagaimana Islam pada masa Kemerdekaan, apa yang dilakukan umat Islam menghadapi kebijakan pemerintahan junta militer di Myanmar.

\section{METODE PENELITIAN}

Penulisan ini mengikuti prosedur dan kaidah-kaidah yang berlaku dalam penelitian sejarah, yang tersusun dalam empat langkah : heuristik, kritik sumber,

${ }^{3}$ Saifullah, Sejarah dan Kebudayaan Islam di Asia Tenggara, Yogyakarta : Pustaka Pelajar, 2010. Hlm. 189.

${ }^{4}$ Saiful Muzani, Pembangunan dan Kebangkitan Islam di Asia Tenggara, Jakarta : LP3ES, 1993. hlm 48 
interpretasi dan historiografi ${ }^{5}$. Heuristik adalah aktifitas mencari dan mengumpulkan sumber-sumber penelitian yang relevan. Langkah berikutnya adalah kritik sumber, di mana kritik sumber merupakan upaya untuk mempermasalahkan kesejatian sumber. Selanjutnya adalah melakukan interpretasi data dengan menggunakan pendekatan sosial dan politik dan sejumlah paradigma umum untuk melihat masalah yang sedang diteliti. Kegiatan terakhir adalah pendiskripsian secara logis dan sistematis, fakta-fakta yang telah diolah secara analisis ke dalam bentuk tulisan (historiografi).

\section{HASIL PENELITIAN DAN PEMBAHASAN}

\section{A. Zaman Kasultanan Islam.}

Sejak tahun 1430-1638, wilayah Burma dikuasai muslim dengan system kerajaan. Saat itu system kerajaan seperti perdana menteri, menteri pertahanan, menteri peradilan, hakim dan tentara sudah terbentuk ${ }^{6}$. Pemerintahan Muslim di Arakan berlangsung beberapa abad dan meluas ke selatan hingga mencapai Moulmein pada masa pemerintahan Sultan Salim Shah Rasagri (1593 - 1612 M). Bahasa Persia merupakan bahasa resmi bagi Negara Islam Arakan yang beribukota di Myohaung. Pada saat itu banyak pedagang muslim Arab yang menyebarkan agama Islam. Sistem pembayaran menggunakan koin yang berisi kalimat syahadat.

Perdagangan kaum muslim di Asia Tenggara mencapai puncaknya hingga abad ketujuh belas. Kota-kota di pesisir Burma masuk dalam jaringan perdagangan kaum muslim yang lebih luas. Pada abad XVII, sebagian besar provinsi yang terletak di jalur perdagangan dari Mergui ke Ayuthia praktis dipimpin oleh gubernur muslim. Sejak abad XV hingga pertengahan abad XVIII, , tentara Burma memasukkan kaum muslim dalam unit pegawai kerajaan sebagai pasukan artileri dan pasukan penembak. Pada masa pemerintahan Raja Pagan-Min (1846-1853), seorang muslim diangkat menjadi gubernur Amarapura yang

\section{${ }^{5}$ Nugroho Notosusanto, Norma-norma dalam Penelitian dan Penulisan} Sejarah, Jakarta : Dephankam, 1970.

6 "Muslim Myanmar Minoritas yang Tertindas", Majalah UMMI . Edisi 9/XIV/2003, hlm 68. 
memperoleh wewenang luas dari raja. Pada tahun 1855, gubernur Pagan juga seorang muslim.

Di wilayah Arakan karena factor kedekatan dengan India maka terjalinlah hubungan diplomatic, politik, perdagangan dan budaya dengan India. Pengaruh muslim sangat jelas sehingga raja Arakan menggunakan nama dan gelas Islam. Banyak kalangan Muslim yang menduduki posisi penting dalam pemerintahan kerajaan Arakan.Sejak abad XV hingga XVI, Arakan menjadi smakin berorientasi kepada Kerajaan Moghul di India. Pada tahun 1784, penduduk Burma pengikut Budha berhasil menaklukkan Negara Islam Arakan. Pendudukan wilayah Arakan kemudian dilanjutkan oleh Penjajah Inggris. Antara 1824-1826 terjadi perang Anglo-Burma yang pertama. Perang berakhir pada 24 Pebruari 1426 ditandai dengan Perjanjian Yandabo yang menyebabkan Arakan dan Tenasserim dimasukkan ke wilayah British-India. Meskipun Negara bisa ditaklukkan oleh orang Burma maupun Inggris, namun posisi kaum muslim di Arakan tidak tergoyahkan. Kejayaan kerajaan Arakan berakhir saat raja Birma yang bernama Baoday menginfasi Arakan pada tahun 1857. Pada saat itu penduduk Arakan banyak yang mengungsi ke Benggali. Pada masa kolonial Inggris muslim Rohingya mendapat sedikit keleluasaan di bawah "Komite Kebebasan" yang diketuai oleh Umrah Meah dan Zahirudij Ahmed ${ }^{7}$.

Kasultanan Yunnan di bawah peemrintahan Sultan Sulaiman jatuh ketangan kekaisaran China pada 1873. Kejatuhan ini mendorong munculnya gelombang baru pendatang China ke bagian utara Burma untuk mencari suaka politik. Mulai abad XVIII dan XIX, di beberapa kota di Burma jumlah orang muslim cukup diperhitungkan. Orang Muslim banyak bekerja dalam pemerintahan hingga jatuhnya Kerajaan Burma di Mandalay pada 1885.

Populasi Islam di Myanmar sempat meningkat pada masa penjajahan Britania Raya, dikarenakan banyaknya umat Muslim di India yang bermigrasi ke Myanmar. Imigran muslim ini datang dengan keinginan untuk mendapatkan penghidupan dan lapangan kerja baru di wilayah Burma. Memasuki abad XX, setengah penduduk kota Rangoon adalah orang India, yang sebagiannya adalah

\section{${ }^{7}$ Ibid}


muslim. Tapi, populasi umat Islam semakin menurun ketika perjanjian IndiaMyanmar ditandatangani pada tahun 1941. Keputusan digabungkannya Arakan menjadi bagian dari Burma, bertentangan dengan keinginan mayoritas penduduknya yang beragama Islam dan ingin bergabung dengan India. Tahun 1942 penguasa Burma yang beragama Budha kembali melancarkan serangan pada suku Muslim Rohingya. Sekitar 100.000 muslim terbunuh dan ratusan lainnya mengungsi ke Bangladesh. Minoritas Muslim kembali mendapat tekanan saat Myanmar merdeka dari Inggris tahun 1948.

\section{B. Islam pada Masa Kemerdekaan.}

Burma mencapai kemerdekaannya dari Inggris pada tahun 1948. Umat Islam Rohingya merasa dikucilkan dari kemerdekaan itu. Hal ini ditandai dengan tidak diundangnya satu pun perwakilan umat Islam Rohingya saat perjanjian penyatuan Burma ditandatangani pada 12 September 1947 di Pinlong. Perwakilan dari berbagai etnis di Burma setuju untuk merebut kemerdekaan dari Inggris dan kemudian membentuk Negara federal Burma. Etnis Rohingya sama sekali tidak dilibatkan dalam proses ini. Berbeda dengan etnis lainnya, etnis Rohingya kehilangan haknya, bahkan wilayahnya (Arakan) diserahkan kepada etnis Rakhin yang beragama Buddha, walaupun populasinya kurang dari $10 \%$ penduduk Arakan. Sejak saat itulah hak-hak etnis Rohingya berusaha dihilangkan oleh para politisi Buddha Burma.

Burma melaksanakan sistem politik demokrasi liberal hingga Maret 1962, ketika terjadi kudeta militer. Sejak saat itu di Burma dimulailah pemerintahan junta militer. Di bawah kepemimpinan junta militer Jendral Ne Win dan Program Partai Sosialis Birma (Burma Socialist Programme Party/BSPP), umat Islam semakin tertindas. Semenjak pemerintahan junta militer, hak-hak politik dikekang, juga dalam bidang social budaya, hal ini ditandai dengan ditutupnya tempat-tempat belajar bahasa Rohingya pada tahun 1965 oleh pemerintahan junta militer. Tentara Myanmar banyak terlibat dalam sentimen keagamaan. Dengan alasan Myanmar adalah negara Budha mereka sengaja melakukan pelecehan terhadap Islam dan muslim Myanmar. Penggempuran masjid di satu desa secara 
mendadak bukan hal yang baru bagi muslim Myanmar. Sentimen anti muslim dimotori oleh penguasa militer Myanmar atau yang dikenal sebagai State Law and Order Restoration Council (SLORC) dan Tentara Demokrat Budha Kayin (DKBA) . Selain menghancurkan masjid, mereka juga membakar Al-Quran, memaksa muslim Myanmar untuk memakan babi bahkan memberikan pilihan masuk Budha atau diusir dari kampung mereka. Perusakan terang-terangan terjadi sekitar tahun 1997. Sedangkan pada tahun 2001 muslim Myanmar yang terbunuh cukup besar rata-rata rumah dan masjid mereka hancur.

Peristiwa perusakan patung Budha oleh Taliban di Afganistan dan serangan 11 September 2001 di Amerika Serikat mengakibatkan tekanan terhadap muslim Myanmar bertambah keras. Banyak terjadi kekerasan di daerah yang berpenduduk mayoritas muslim yakni di sekitar Prome, Pegu, dan di Arakan. Kondisi ini menyebabkan banyak masyarakat muslim Myanmar yang melarikan diri ke negara-negara tetangga. Sekitar 1.500 .000 jiwa muslim Myanmar mengungsi ke Malaysia, Bangladesh, Thailand, dan lain-lain.

Muslim Myanmar yang menjadi minoritas di tengah-tengah masyarakat Budha banyak mengalami penindasan. Nilainya semakin buruk karena pernah mendapat sedikit kebebasan pada masa kolonial Inggris. Mereka dianggap sebagai kaki-tangan kolonial Inggris. Tentara Myanmar disinyalir menggunakan para pendeta Budha untuk menggempur masjid di perkampungan muslim. Pasukan militer banyak melakukan perusakan terhadap masjid di samping merobek dan membakar Al-Quran. Kerja paksa dan kekerasan terhadap wanita juga mengiringi kekejaman ini. Pemerintah militer punya andil besar dalam mempersempit gerak muslim Myanmar. Pemerintah mengontrol halhal yang sifatnya pribadi seperti pernikahan. Muslimah Myanmar dilarang menikah sebelum berusia 25 tahun. Kalupun ingin menikah, banyak sekali birokrasi yang harus dihadapi termasuk segala macam perizinan. Hal ini adalah upaya pemerintah Myanmar untuk membatasi populasi muslim.

Muslim di Myanmar juga melakukan perlawanan terhadap tindakan kesewenang-wenangan ini. Salah satu bentuk perlawanan mereka adalah membentuk organisasi, salah satunya adalah Oganisasi Nasional Arakan 
Rohingya (ARNO). Organisasi ini merupakan gabungan dari Front Islam Rohingya (ARIF) yang dipimpin oleh Nurul Islam, Organisasi Solidaritas untuk Rohingya (RSO) yang dipimpin oleh Dr. Yunus dan RSO pimpinan Prof. Muhamma Zakaria. Sebagai alat perjuangan, ARNO juga memiliki sebuah radio yaitu Radio Rohingya yang mengudara dengan bahasa asli mereka. Siarannya dapat diakses via internet. Radio ini menjadi corong perjuangan ARNO untuk kemerdekaan dengan cara menyebarluaskan informasi hangat yang menyangkut muslim Rohingya baik di dalam negeri maupun di pengungsian.

Pada masa junta militer, muslim Rohingya mendapat perlakuan buruk dari pemerintah. Junta militer berusaha menyingkirkan mereka, dengan menolak kewarganegaraan penuh Myanmar, mereka menyebutnya sebagai warga Negara bagian Rakhine. Rezim militer menekan mereka secarav rutin menjadi budak, sangat membatasi hak-hak mereka untukm perjalanan dan menikah, menolak akses mereka untuk pendidikan dan perawatan medis. SDi Sittwe, ibukota Rakhine, Rohingya menjalani hidup penuh kemiskinan. Mereka dipaksa bekerja dalam pembangunan jalan dengan gaji yangamat kecil, di samping mengandalkan hidup dari pertanian dan perikanan. Muslim Rohingya di Negara bagian Arakan terus mengalami berbagai bentuk diskriminasi berat dalam bidang hokum, ekonomi, pendidikan dan sosial ${ }^{8}$. Muslim Burma terus berjuang melawan ketidakadilan dan penindasan yang diberlakukan oleh rezim militer yang berkauasa di Myanmar.

\section{Kebijakan Militer terhadap Minoritas Muslim}

Secara politik akan tampak bahwa kaum muslim Myanmar menikmati proteksi dan kebebasan yang lebih besar selama periode demokrasi. Mereka tidak hanya mempunyai wakil yang cukup baik di pemerintahan tetapi juga merupakan elemen politik yang penting dalam kehidupan politik di Burma. Kudeta militer tahun 1962 telah mencekik ruang politik oposisi dan mempersempit ruang partisipasi muslim di bidang politik. Muslim Myanmar yang menjadi minoritas di

${ }^{8}$ Laporan Kebebasan Beragama Internasional AS tahun 2010, Koran Muslim, 25 Pebruari 2011. 
tengah-tengah masyarakat Budha banyak mengalami penindasan. Nilainya semakin buruk karena pernah mendapat sedikit kebebasan pada masa kolonial Inggris. Mereka dianggap sebagai kaki-tangan kolonial Inggris. Tentara Myanmar disinyalir menggunakan para pendeta Budha untuk menggempur masjid di perkampungan muslim. Pasukan militer banyak melakukan perusakan terhadap masjid di samping merobek dan membakar Al-Quran. Kerja paksa dan kekerasan terhadap wanita juga mengiringi kekejaman ini. Pemerintah militer punya andil besar dalam mempersempit gerak muslim Myanmar. Pemerintah mengontrol halhal yang sifatnya pribadi seperti pernikahan. Muslimah Myanmar dilarang menikah sebelum berusia 25 tahun. Kalupun ingin menikah, banyak sekali birokrasi yang harus dihadapi termasuk segala macam perizinan. Hal ini adalah upaya pemerintah Myanmar untuk membatasi populasi muslim.

Muslim di Myanmar juga melakukan perlawanan terhadap tindakan kesewenang-wenangan ini. Salah satu berntuk perlawanan mereka adalah membentuk organisasi, salah satunya adalah Oganisasi Nasional Arakan Rohingya (ARNO). Organisasi ini merupakan gabungan dari Arakan Rohingya Islamic Front (ARIF) yang dipimpin oleh Nurul Islam, Organisasi Solidaritas untuk Rohingya (RSO) yang dipimpin oleh Dr. Yunus dan RSO pimpinan Prof. Muhamma Zakaria. Sebagai alat perjuangan, ARNO juga memiliki sebuah radio yaitu Radio Rohingya yang mengudara dengan bahasa asli mereka. Siarannya dapat diakses via internet. Radio ini menjadi corong perjuangan ARNO untuk kemerdekaan dengan cara menyebarluaskan informasi hangat yang menyangkut muslim Rohingya baik di dalam negeri maupun di pengungsian.

Organisasi perlawanan ARIF dan RSO mencoba membentuk aliansi dengan All-Burma Moslem Union (ABMU) untuk menentang pemerintahan militer Myanmar yang dodominasi oleh penganut Budha ${ }^{9}$. Masalah agama Islam ini juga mengancam keutuhan wilayah Myanmar. Myanmar harus mengatasi tuntutan kemerdekaan orang-orang Rohingya di Arakan. Upaya ini dilakukan dengan sangat hati-hati, sebab lokasinya serta solidaritas muslim bias merembet

9 Kardiyat Wiharyanto, Sejarah Myanmar Modern, Yogyakarta : Universitas Sanata Dharma, 1993, hlm. 103. 
dan memancing keterlibatan Bangladest maupun Negara-negara terdekat yang lain.

Pemerintah Myanmar menyatakan bahwa orang-orang Rohingya bukanlah warganegaranya. Menurut pemrintah Myanmar, bahwa dari 135 etnis yang tinggal di Myanmar, tidak ada yang bernama Rohingya. Nama Rohingya menurut pemerintah Myanmar adalah julukan yang diberikan oleh kelompok pemberontak di negera-negara bagian Arakan.Kelompok ini, sejak Perang Burma I (AngloMyanmar) tahun 1824, memasuki bagian Arakan secara illegal. Rohingya adalah julukan yang diberikan kepada orang-orang Burma di Negara bagian Arakan, yang mendapat pengaruh Islam, yang menuntut suatu negara merdeka, terpisah dari Myanmar. Muslim Rohingya merupakan mayoritas penduduk di Arakan. Namun jumlah itu terus berkurang akibat dari pengusiran hingga pembunuhan. Saat ini Muslim Rohingga sedikit tersisa di selatan Arakan dan mayoritasnya tinggal di bagian utara Arakan.

Permasalahan kewarganegaraan Rohingga memang sulit dipecahkan. Dari sudut hukum, pernyataan pemerintah Myanmar bahwa mereka tidak memiliki dokumen apapun penolakan itu bias diterima. Namun dari sudut historis, orangorang Rohingga buikanlah oaring yang baru beberapa tahun berada di Myanmar. Orang Rohingga sudah ratusan tahun sejak nenek moyang mereka tinggal dan menetap di kawasan yang kini menjadi Negara bagian Arakan. Kata Rohingya sendiri berasal dari kata Rohang, yang merupakan nama lama dari Negara bagian Arakan. Etnis Rohingya sudah tinggal di Arakan sejak abad ke-7 Masehi.

Suku Burma yang mayoritas di Myanmar, menunjukkan sikap yang tidak tulus dalam menerima etnis lain sebagai warganegara Myanmar. Suku Burma kelihatan angkuh ketika berhadapan dengan suku-suku minoritas khususnya yang beragama Islam, Kristen dan Hindu. Suku Rohingga yang Islam, Suku Karen yang Kristen dan Suku Naga yang Hindu mereka dicurigai loyalitasnya kepada tanah air mereka.

Permasalah muncul suku-suku minoritas ini muncul berkaitan dengan penarikan tapal batas antara India dan Myanmar setelah dipisahkan dari British 
India pada tahun $1935^{10}$. Akibat pemisahan ini orang-orang Islam di Kawasan timur Bangladest marus masuk ke wilayah Myanmar. Demikian juga Suku Naga yang beragama Hindu harus masuk juga ke wilayah Myanmar. Sedangkan untuk orang Karen yang Bergama Kristen, kecurigaan muncul didorong oleh pernyataan sementara peninjau Barat yang memandang kawasan penduduk Karen itu sebagai kubu peradaban Barat dan Agama Kristen di Myanmar ${ }^{11}$.

Penindasan terhadap suku minoritas di Myanmar, termasuk Suku Rohingga, Karen dan Naga, dengan pendekatan Political Cultural, berhubungan dengan watak isolative dan ekslusif yang dimiliki suku Burma. Sikap mental ini jika dirinci ada empat unsure yaitu kepatuhan yang pasif, ketakutan berbuat salah, tidak berani menghadapi tantangan dan terlalu dengan ritual ${ }^{12}$. Sumber sikap negative terhadap sekelilingnya yang melekat pada orang Burma, terutama pada praktek pengasuhan anak. Para ibu bertindak antar dua ekstemitas, antara kehangatan, kesabaran dan kepedulian. Hasilnya, anak setelah dewasa tidak dapat mengendalikan diri seperti biasa dilakukan orang lain. Sentimen keagamaan sangat tebal sehingga di Myanmar hampir tidak ada interaksi antar golongan, baik secara etnis maupun secara religius.

Suatu pemerintahan yang baik mestinya dicintai dan didukung oleh seluruh rakyatnya, tetapi tidak di Myanmar. Sebagian rakyatnya justru membenci pemerintahan yang ada. Berbagai gerakan separatis dari kelompok etnis minoritas telah mewarnai sejarah panjang Myanmar. Gerakan separatis ini telah ada sejak Jendral Ne Win melancarkan kudeta militer dan mengambil alih kekuasaan dari pemerintahan sipil Perdana Menteri U Nu. Rohingya National Liberation Front (RNLF) terus mengadakan perlawanan terhadap pemerintah militer Burma dalam rangka mencapai tujuannya yaitu memisahkan diri dari Burma. Kawthoolay

10 Ibid, hlm. 104

11 Suwiryadi, Dunia Sekitar Kita : Burma Pos Depan Bangsa Mongol, Jakarta : Djambatan, 1952, hlm 53.

12 Merupakan analisis dari Lucian W. Pye, sebagaimana dikutip oleh Umar Bakry Suryadi, "Memahami Isolasionisme Myanmar”, Kompas, tanggal 2 Maret 1992. 
Muslim National Liberation Front (KMNLF) berkolaborasi dengan Karen National Liberation Army (KNLA) untuk menentang pemerintah Burma ${ }^{13}$.

Pada tanggal 23 Juli 1988 Jendral Ne Win mengundurkan diri, hal ini membangkitkan semangat optimisme bagi rakyat Myanmar yang ingin mewujudkan demokrasi di negerinya. Optimisme makin terlihat jelas ketika konggres mengusulkan adanya suatu referendum untuk mengakhiri totaliterisme di Myanmar. Demonstrasi pada tanggal 8 Agustus 1988 yang melibatkan seluruh rakyat Myanmar membangkitkan optimisme banyak orang baik di dalam maupun luar negeri. Indikasi optimisme terlihat dari beberapa hal ${ }^{14}$ :

1. Mundurnya Sein Lwin (Penganti Ne Win) sebagai kepala Negara pada tanggal 12 Agustus 1988, setelah adanya pembantaian brutal dari aparat militer terhadap para demonstran di seluruh negeri. Penggantinya adalah maung-Maung, seorang sejarawan dan kawan akrab Jendral $\mathrm{Ne}$ Win. Penggantian ini hanya mampu meredam sementara karena semua orang tahu bahwa Maung-Maung adalah sekedar bonekanya Jendral Ne Win.

2. Proses Demokratisasi masyarakat mulai berkembang. Ini terlihat dari adanya pengelompokan dan adanya usaha-usaha rekonsiliasi di antara kelompok-kelompok oposan. Termasuk di dalamnya usaha mempertemukan kelompok oposan di perkotaan dan kelompok oposan di pedalaman (kelompok etnis minoritas).

3. Takanan internasional sudah mencapai puncaknya ketika negera-negara Barat dan Jepang memboikot secara ekonomi terhadap Myanmar jika penindasan terus berlangsung.

Optimisme ini tidak berlangsung lama. Pada tanggal 16 September 1988, Jendral Saw Maung melakukan kudeta militer terhadap Maung-Maung dan diikuti dengan penindasan yang kejam terhadap para demonstran. Untukmmeredakan pemberontakan suku-suku minoritas, rezim Saw maung pada bulan Mei 1989 mengubah nama Republik Burma menjadi Myanmar dan

${ }^{13}$ Saiful Muzani, Pembangunan dan Kebangkitan Islam di Asia Tenggara, Jakarta : LP3ES, 1993, hlm. 50.

${ }^{14}$ Kirdiyat Wiharyanto, op.cit, hal 107 
menganti nama ibukota Ranggon menjadi Yangoon. Perubahan ini dimaksudkan untuk member kesan bahwa Myanmar bukan hanya milik suku Burma, tetapi juga suku-suku lain yang berdomisili di Myanmar.

Pemilihan Umum pada 27 Mei 1990 berakhir dengan kemenangan pihak sipil, di mana Aung Sang Suu Kyi meraih 392 kursi dari 485 kursi yang ada. Namun hasil pemilu tesebut ditolak oleh rezim militer yang berkuasa. Mereka tidak mengakui hasi-hasil pemilu yang demokratis itu, dan juga tidak mau menyerahkan kekuasaan kepada pemenangnya.

Pemerintah tandingan dibentuk untuk mesikapi sikap keras pemerintahan militer Myanmar. Pemerintahan tandingan itu adalah National Coalization Government of the Union Burma (NCGUB). NCGUB yaitu suatu koalisi antara tokoh suku Burma, Karen dan kachin yang berkedudukan di Manerplaw, suatu kota yang terletak dekat dengan perbatasan Muangthai ${ }^{15}$. Tindakan keras justru semakin banyak dilakukan oleh pemerintah militer. Terjadi serangan besar-besaran baik terhadap suku Karen maupun Rohingya. Akibatnya banyak rakyat yang lari ke Negara tetangga, misalnya Bangladesh harus menampung ribuan pengungsi Rohingya yang beragama Islam. Untuk itu diperlukan peran PBB dan dunia internasional untuk memecahkan masalah kemanuasian di Myanmar yang terjadi sampai saat ini.

Ada beberapa kebijakan Pemerintahan Junta Militer Myanmar terhadap umat Islam di Myanmar, khususnya terhadap muslim Rohingya. Kebijakan itu di antaranya :

1. Penolakan pemberian kewarganegaraan terhadap etnis Rohingya sehingga etnis Rohingya menjadi bangsa tanpa kewarganegaraan. Hal ini dijadikan alas an pembenaran junta militer untuk mengusir etnis Rohingya dari tanah leluhurnya, akibatnya lebih dari setengah populasi Rohingya terusir dari Arakan.

2. Pembatasan untuk berpindah. Etnis Rohingya yang tersisa di Myanmar mendapatkan larangan bepergian dari desa satu ke desa lainnya, untuk ke luar desanya harus dengan izin yang tidak mudah didapatkan.

15 Ibid, hlm 110 
3. Pembatasan dalam bidang ekonomi. Pihak militer menolak memberikan izin usaha bagi etnis Rohingya, serta menerapkan pajak yang tinggi. Akibatnya sebagian besar lahan pertanian, tambak dan property milik etnis Rohingga telah disita secara paksa, sebagai konsekuensi karena tidak bias membayar pajak.

4. Pembatasan dalam bidang pendidikan. Anak-anak etnis Rohingya dilarang masuk ke universitas yang ada di Myanmar dan pada saat yang bersamaan juga dilarang melanjutkan pendidikan tinggi ke luar Myanmar.

5. Pembunuhan, penahanan dan penyiksaan.Penyiksaan dan penahanan secara illegal dilakukan setiap hari di Arakan, ratusan etnis Rohingya hilang dan tidak diketahui nasibnya.

6. Kerja Paksa. Kamp konsentrasi bagi penduduk etnis Rohingya tidak memungkinkan mereka untuk bepergian sehingga memudahkan pemerintahan militer menjadikan mereka sebagai pekerja paksa.

7. Pengusiran Etnis Rohingya dari desa mereka.

8. Pelecehan terhadap kaum wanita dan pembatasan pernikahan.

9. Kerusuhan anti Rohingya.

10. Penghancuran ratusan Masjid dan Madrasah, serta pelarangan kaum muslimin untuk melakukan berbagai kegiatan ibadah.

\section{KESIMPULAN}

Perkembangan Islam di Myanmar dimulai sekitar abad ke-9. Mereka berasal dari kerajaan Arakan yang teletak di daerah Benggali (India) dan China. Pada saat itu banyak pedagang muslim Arab yang menyebarkan agama Islam di Myanmar. Sejak tahun 1430 sampai 1638 wilayah Arakan dikuasai muslim dengan sistem kesultanan. Saat itu sistem kerajaan seperti perdana mentri, mentri pertahanan, mentri peradilan, hakim dan tentara sudah terbentuk. Sistem pembayaran menggunakan koin yang berisi kalimat syahadat. Kejayaan kerajaan Arakan berakhir saat raja Birma yang bernama Baoday menginvasi Arakan pada tahun 1857. Pada saat itu penduduk Arakan banyak yang mengungsi ke Benggali. Pada masa kolonial Inggris populasi Islam meningkat. Muslim Rohingya 
mendapat sedikit keleluasaan di bawah "Komite Kebebasan" yang diketuai oleh Umrah Meah dan Zahirudij Ahmed. Pada tahun 1941 terjadi perjanjian pemisahan Myanmar dari India. Muslim Myanmar yang menjadi minoritas di tengah-tengah masyarakat Budha banyak mengalami penindasan. Nilainya semakin buruk karena pernah mendapat sedikit kebebasan pada masa kolonial Inggris. Mereka dianggap sebagai kaki-tangan kolonial Inggris.

Pemerintahan junta militer yang berkuasa sejak tahun 1962 menyebabkan Islam makin tertindas. Tentara Myanmar disinyalir menggunakan para pendeta Budha untuk menggempur masjid di perkampungan muslim. Pasukan militer banyak melakukan perusakan terhadap masjid di samping merobek dan membakar Al-Quran. Kerja paksa dan kekerasan terhadap wanita juga mengiringi kekejaman ini. Pemerintah militer punya andil besar dalam mempersempit gerak muslim Myanmar. Pemerintah mengontrol hal hal yang sifatnya pribadi seperti pernikahan. Muslimah Myanmar dilarang menikah sebelum berusia 25 tahun. Kalupun ingin menikah, banyak sekali birokrasi yang harus dihadapi termasuk segala macam perizinan. Hal ini adalah upaya pemerintah Myanmar untuk membatasi populasi muslim. Tahun 1996 terjadi intensitas yang tinggi perlakuan sewenang-wenang dari pemerintahan militer Myanmar. Puncaknya pasca peristiwa 11 September 2001 di Amerika Serikat mengakibatkan tekanan terhadap muslim Myanmar bertambah keras. Tercatat sekitar 1.500.000 muslim Myanmar harus mengungsi ke Malaysia, Bangladesh, Thailand dan lain-lain. 


\section{DAFTAR PUSTAKA}

Ahmad Ibrahim, Sharon Siddique, Yasmin Hussain (ed). (1989). "Reading on Islam in Southeast Asia", Islam Asia Tenggara : Perspektif Sejarah (a.b. A Setiawan Abadi), Jakarta : LP3ES.

Kardiyat Wiharyanto, (1993), Sejarah Myanmar Modern, Yogyakarta : Universitas Sanata Darma.

Laporan Kebebasan Beragama Internasional AS tahun 2010, Koran Muslim, 25 Pebruari 2011.

“Muslim Myanmar Minoritas yang Tertindas”, dalam Ummi, Edisi 9/XIV/2003.

Nugroho Notosusanto, Norma-norma dalam Penelitian dan Penulisan Sejarah, Jakarta : Dephankam, 1970.

Saifullah, (2010), Sejarah dan Kebudayaan Islam di Asia Tenggara, Yogyakarta : Pustaka Pelajar.

Saiful Muzani, (1973). Pembangunan dan Kebangkitan Islam di Asia Tenggara, Jakarta : LP3ES.

Suwiryadi, (1952), Dunia Sekitar Kita : Burma Pos Depan Bangsa Mongol, Jakarta : Djambatan.

Umar Bakry Suryadi, (1992), "Memahami Isolasionisme Myanmar," Kompas, tanggal 2 Maret 1992. 